Tropical Journal of Pharmaceutical Research May 2016; 15 (5): 1083-1088

ISSN: $1596-5996$ (print); 1596-9827 (electronic)

(C) Pharmacotherapy Group, Faculty of Pharmacy, University of Benin, Benin City, 300001 Nigeria.

All rights reserved.

Available online at http://www.tjpr.org

Review Article

http://dx.doi.org/10.4314/tjpr.v15i5.26

\title{
Role of Erythropoietin in Renal Anemia Therapy
}

\author{
Xuekun Xing*, Wenbo Zhang and Huishan Sun \\ Department of Life Sciences and Technology, Xinxiang Medical University, Xinxiang, Henan 453003, PR China \\ *For correspondence: Email: biyingxiao@163.com; Tel: +86-15537372156
}

Received: 11 January 2016

Revised accepted: 16 April 2016

\begin{abstract}
Renal anemia is a common complication of chronic renal failure caused by erythropoietin deficiency; targeting erythropoietin is a common approach to renal anemia treatment. This paper describes the role of erythropoietin and others drugs in renal anemia treatment, as well as the cause of erythropoietin resistance.
\end{abstract}

Keywords: Chronic renal failure, Renal anemia, Erythropoietin resistance

Tropical Journal of Pharmaceutical Research is indexed by Science Citation Index (SciSearch), Scopus, International Pharmaceutical Abstract, Chemical Abstracts, Embase, Index Copernicus, EBSCO, African Index Medicus, JournalSeek, Journal Citation Reports/Science Edition, Directory of Open Access Journals (DOAJ), African Journal Online, Bioline International, Open-J-Gate and Pharmacy Abstracts

\section{INTRODUCTION}

The loss in whole or in part of kidney function results in renal failure, representing a significant threat to human health. "Renal anemia" refers to the various factors that cause erythropoietinrelated or toxic uremic plasma substances to interfere with red blood cell metabolism, leading to anemia. Renal anemia is a common complication of chronic renal insufficiency, which is related to various degrees of renal dysfunction. Erythropoietin (EPO) is a 34000 Da glycoprotein the main chain of which is comprised of 193 amino acids. EPO a hormone-like substance secreted $90 \%$ by renal interstitial cells and $10 \%$ by liver cells. The kidney is the organ most responsible for controlling the level of EPO in serum, and any damage to renal tubular or glomerular tissue can inhibit the production of EPO and cause renal tissue ischemia and hypoxia, which can then further induce the formation of EPO [1]. EPO cannot be directly stored in the body after it is produced, but rapidly enter the metabolic process [2]. In general, serum EPO levels are regulated by the feedback regulation of hemoglobin and red blood cell pressure - once the feedback regulation appears abnormal (i.e., fluctuating EPO levels), the body undergoes a sustained rise in serum EPO levels that ultimately lead to kidney damage [3].

\section{ERYTHROPOIETIN AND RENAL ANEMIA}

EPO can stimulate the proliferation and differentiation of cells in the bone marrow [4], and is a humoral factor that enhances the formation of red blood cells. EPO can also promote the differentiation of stem cells into the red blood cell line, and promote the synthesis of hemoglobin and the flow of blood into peripheral blood vessels [5]. EPO, activated by EPO receptors, promotes the differentiation and proliferation of the burst-forming unit-erythroid (BFU-E) cells to transform the red line into a mature red blood cells [6] (Figure 1).

In this review, we found that EPO treatment can significantly improve renal anemia patients in terms of oxygen level, immune function, and so on; that the use of EPO can reduce transfusionrelated complications such as iron overload or blood infection [7]. To this effect, erythropoietin not only creates mature red blood cells but also has an important role in heart protection. 


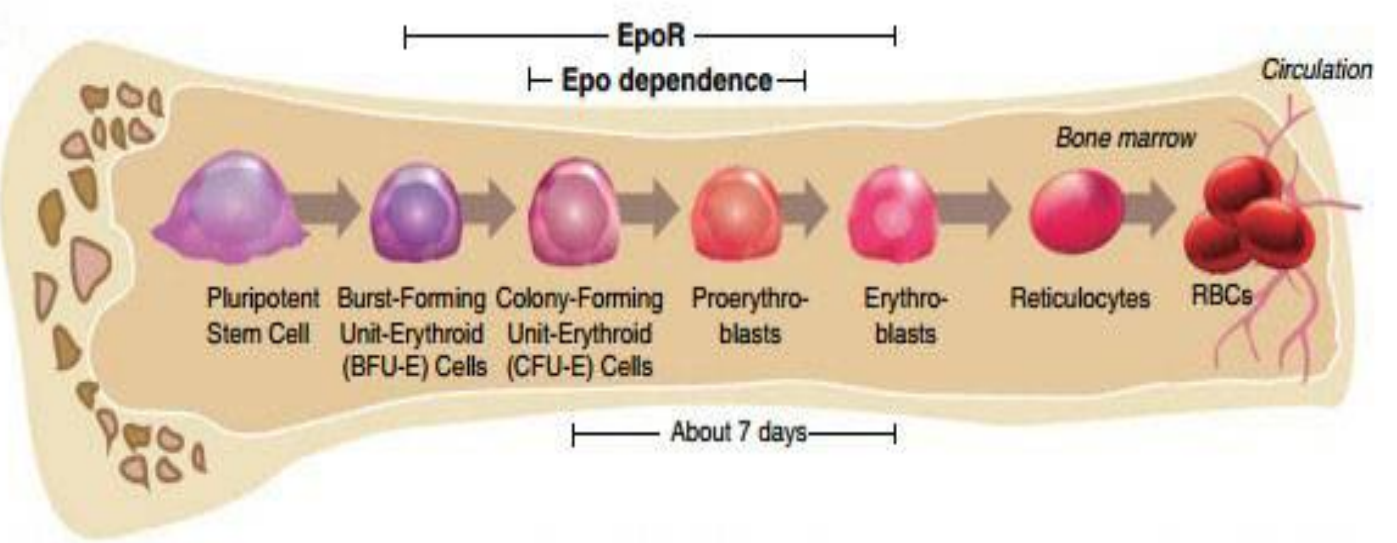

Figure 1: The process of erythropoiesis. Depend on Epo and EpoR, erythroid progenitors differentiation into mature red blood cells. Quote from Ann Hematol2014; 93(2):181-192. Elliott S1, Sinclair A, Collins H, Rice L, Jelkmann W. Progress in detecting cell-surface protein receptors: the erythropoietin receptor example

In addition, in recent years, EPO has shown protective effect against apoptosis and on the ischemic heart, which can improve left ventricular function [8].

\section{COMBINED EFFECTS OF DIFFERENT DRUGS AND ERYTHROPOIETIN}

\section{Iron sucrose}

Clinically, iron supplements can be roughly divided into oral and intravenous administration categories. In the reticuloendothelial system of patients with uremia and disorder of iron release and iron malabsorption in the gastrointestinal tract, oral administration typically fails to fully meet EPO treatment requirements as far as iron demand in the bone marrow [9]. The utilization rate of intravenous iron supplementation, conversely, is fairly high and with little gastrointestinal reaction, which can increase the iron utilization and improve iron reserves, overcoming the reticuloendothelial system iron release barrier.

Iron ions are released from the complexes of intravenous iron assisted by activated macrophages in the reticuloendothelial system. One part of iron bind with apoferritin to form serum ferritsin store in the cell, other part of iron bind with transferrin transferred to transferrin receptor on the surface of the immature red cell, in these process increases iron utilization and the body's iron reserves [10]. Clinical observation has confirmed that on the basis of EPO treatment, and then increased the treatment of iron sucrose, can significantly improve the clinical efficacy, and the adverse reaction of the treatment with sucrose iron after the occurrence of low and mild, can improve symptomatic treatment [11].

\section{L-carnitine}

L-carnitine, an amino acid already prevalent within the tissues of the body, can influence the erythrocyte membrane phospholipid and acylation process and deformation capacity, stabilize the red cell membrane, and increase hematocrits to enhance the body's resistance to various stresses [12]. Cell-level L-carnitine deficiency produces toxic effects, increases normal red cell osmotic fragility, shortens life expectancy, and may cause EPO resistance [13]. Aoun [14] reported that long-term use of EPO in hemodialysis patients accompanied by intravenous L-carnitine supplementation, after nine months of treatment, results in significantly increased hemoglobin $(\mathrm{Hb})$ levels, likely because L-carnitine reduces erythrocyte lipid composition to improve the stability of the red cell membrane, reducing brittleness and prolonging the life of red blood cells. In addition, L-carnitine can improve Na-K-ATPase activity, then increase the conversion of erythrocyte fatty acids and oxidative phosphorylation. The effects of Lcarnitine on bone marrow progenitor cells of red blood cells may also improve the curative effect of EPO, correct the resistance to EPO, and reduce the amount of EPO used by the body [15]. L-carnitine has also been shown to decrease C-reactive protein (CRP), interleukin 1 (IL-1), and tumor necrosis factor (TNF) level, as well as microinflammation in patients who are in remission, effectively alleviating renal anemia [16].

\section{Iron dextran}

Iron dextran is an intravenous iron treatment. After treatment with erythropoietin, anemia patients show increased use of iron and imbalance of iron storage in the body. The 
efficacy of intravenous iron supplementation is good, but it can cause acute adverse reaction and delayed reaction similar to allergic reaction, such as respiratory problems, hypotension, chest pain, vasogenic edema, and urticaria [17]. Iron dextran dispersion tablets combined with Lcarnitine injection and erythropoietin can significantly improve EPO efficacy, reducing EPO and leading to significant improvement in anemia with fewer side effects, in addition to reducing dialysis syndrome [18].

\section{Reduced glutathione}

In patients with chronic renal failure, the retention of metabolic products, the decrease of antioxidant activity, and the increase of oxidant activity, resulting in reduced glutathione levels and elevated levels of oxidized glutathione. Red blood cell membrane molecules form disulfide bonds, so that the aggregation of macromolecules on the red blood cell membrane, resulting in red blood cell deformation [19].

Glutathione, a three peptide compound comprised of glutamic acid, cysteine, and glycine, is an important metabolic regulator in the cell. It can provide thiol and cysteine and maintain normal metabolism and physiological activities in the cell so as to keep the cell membrane intact [20]. It also can combine with pro electrons or reactive oxygen species to eliminate lipid peroxide, which protects the cell from damage [21]. Treating chronic renal failure with exogenous reductive glutathione can improve the reduction of red blood cells, reduce the concentration of oxidized glutathione, decrease the ratio of oxidized/reduced glutathione, stabilize the red blood cell membrane, and prolong the life of the red blood cell [22]. Research has shown that the effects of supplemental reductive glutathione on anemia are remarkable than only use erythropoietin [23].

\section{Vitamin C}

Vitamin C, also known as ascorbic acid, is a water-soluble vitamin absorbed by the body in the upper part of the small intestine. Vitamin C plays an important role in the oxidative reduction of metabolic reactions. Vitamin $\mathrm{C}$ is involved in collagen synthesis, scurvy prevention, gum and mouth health, atrophy prevention, prevention of artery hardening, antioxidant synthesis, and anemia treatment [24]. Vitamin C reduces ferric iron, promotes intestinal iron absorption, and improves iron utilization in the liver. In some hemodialysis patients, lack of vitamin $\mathrm{C}$ reduces dialysis clearance [25].
Intravenous application of vitamin C, however, ameliorates iron overload in patients with anemia and increases their hemoglobin level [26]. Vitamin C must be reasonably utilized to prevent side effects, including high serum uric acid, urinary tract stones, and reduced fertility have been reported [27].

\section{Enalapril and irbesartan}

Patients with chronic renal insufficiency have different degrees of renal anemia and hypertension. Enalapril, which hydrolysis into enalaprilat, can inhibit angiotensin converting enzyme reduces the content of angiotensin II causing the blood vessels to relax and blood pressure to drop, easing hypertension. Irbesartan is an angiotensin II receptor blocker that inhibits vascular angiotensin I from converting to angiotensin II, specifically antagonizing the vascular angiotensin converting enzyme (ACE) 1 receptor [28]. By selectively block the binding of angiotensin II and angiotensin converting enzyme 1 receptors, it inhibits vasoconstriction and the release of aldosterone, then reduce blood pressure. Chronic renal disease hemodialysis patients given enalapril and irbesartan treatment show increased hemoglobin and red blood cell count, but the increase was smaller than the single use of EPO group [29]. In effect, hypertensive patients with chronic renal function disease must be given appropriate dose of erythropoietin to ensure enalapril effectiveness.

\section{Trace element copper}

The normal human body generally contains $70-$ $100 \mathrm{mg}$ of copper [30], which is very important for human. Physiological changes of the body iron during hematopoiesis - including absorption, utilization, and storage of iron - are closely related to copper [31]. Copper make inorganic iron into organic iron, (in other words, can transform ferric iron) to push iron from storage into the bone marrow, accelerating the synthesis of hemoglobin and porphyrin.

Copper can accelerate the maturation and the release of immature cells. Copper likely be supplemented to improve iron utilization during renal failure complicated with anemia in patients with low EPO response, but this has only been confirmed in animal experiments and yet needs to be verified through clinical trials [32].

\section{ERYTHROPOIETIN RESISTANCE}

Due to drug sensitivities and other individual differences, about 5 to $10 \%$ of patients still do 
not show sufficient hemoglobin level after the application of EPO (have EPO resistance) [33]. There are many reasons for EPO resistance:

a). The state of micro-inflammatory in chronic dialysis patients have related with the decrease of renal clearance rate, inflammation and inflammatory cytokines. The inflammatory responses of $\mathrm{IL}-1, \mathrm{IL}-6$, TNF- $\alpha$, and other cytokine secretions inhibit the proliferation of bone marrow hematopoietic stem cells, accelerating the destruction of red blood cells and hemoglobin, inhibiting the anti-apoptotic activity of EPO and interfering with iron metabolism, resulting in EPO resistance [34].

b). Secondary hyperthyroidism can lead to osteitis fibrosa, decreasing the bone marrow erythropoiesis and inhibiting endogenous EPO generation.

(c).Aluminum poisoning - the binding of aluminum with iron transferrin interferes with the binding of iron with hemoglobin, which causes EPO resistance [35]. Aluminum can also inhibit hemoglobin synthase.

d). EPO antibodies -- causes of EPO antibodies is unclear. Immune inhibitors can eliminate EPO antibodies in some patients [36].

(e) L-carnitine deficiency, during which the accumulation of metabolites affects carnitine intake. Partial clearance of L-carnitine in hemodialysis patients with varying degrees of L-carnitine deficiency can cause and aggravate anemia [37].

(f) Angiotensin converting enzyme inhibitor (ACEI) class of drugs are also related to EPO resistance, as first reported by Reuter et al [38]. A study involving dialysis patients. The activation of red blood cells after renal transplantation is related to the activation of the renin angiotensin system [39]. ACEI also improves the role of red blood cells in renal transplant recipients, and as such can reduce EPO resistance [40].Other researchers, however, have opposite view on the relationship between EPO resistance and ACEI [41].

(g) IL-1B genes $-511 \quad \mathrm{C} / \mathrm{T}$ and ACE I/D polymorphism are shown to be associated with EPO resistance in a study by Jeong et al [42] conducted on 167 hemodialysis patients.

(h) Iron deficiency is also related to EPI resistance, for a few reasons. After EPO treatment, iron demand increases. Inflammation influences the release and utilization of iron. The barrier of iron absorption. Chronic blood loss, including the residual blood in pipe dialysis and dialysis, hemorrhagic cerebrovascular accident pathway, occult gastrointestinal hemorrhage and frequent collection of blood specimens [43].

\section{CONCLUSION}

EPO can significantly improve the level of oxygen in patients with renal anemia and related compromised immune function. Exogenous EPO and other drugs for renal anemia are safe and efficient. Recent years have seen increasingly extensive research on erythropoietin for the treatment of renal anemia. We believe that in the near future, the erythropoietin resistance problem will be solved and the benefits of the drug fully available to patients.

\section{ACKNOWLEDGEMENT}

This report was supported by Natural Science Research Program of the Education Department in Henan Province, China (no. 15A180020).

\section{CONFLICT OF INTEREST}

No conflict of interest associated with this work.

\section{CONTRIBUTION OF AUTHORS}

We declare that this work was done by the authors named in this article and all liabilities pertaining to claims relating to the content of this article will be borne by the authors.

\section{REFERENCES}

1. Rankin EB, Biju MP, Liu Q, Unger TL, Rha J, Johnson $R S$, Simon MC, Keith $B$ and Haase VH. Hypoxiainducible factor-2 (HIF-2) regulates hepatic erythropoietin in vivo. J Clin Invest 2007; 117: 10681077.

2. Pallet $N$, Bouvier $N$, Legendre $C$, Beaune $P$, Thervet $E$, Choukroun $G$ and Martinez F. Antiapoptotic properties of recombinant human erythropoietin protects against tubular cyclosporine toxicity. Pharmacol Res 2010; 61: 71-75.

3. MacRedmond $R$, Singhera $G K$ and Dorscheid DR. Erythropoietin inhibits respiratory epithelial cell apoptosis in a model of acute lung injury. Eur Respir J 2009; 33: 1403-1414.

4. Lin $H$, Luo $X$, Jin $B$, Shi $H$ and Gong $H$. The Effect of EPO Gene Overexpression on Proliferation and 
Migration of Mouse Bone Marrow-Derived Mesenchymal Stem Cells. Cell Biochem Biophys 2014.

5. Akel S, Petrow-Sadowski C, Laughlin MJ and Ruscetti FW. Neutralization of autocrine transforming growth factor-beta in human cord blood CD34(+)CD38(-)Lin(-) cells promotes stem-cell-factor-mediated erythropoietinindependent early erythroid progenitor development and reduces terminal differentiation. Stem Cells 2003; 21: 557-567.

6. Tsuyuoka $R$, Takahashi $T$, Suzuki A, Sasaki $Y$, Nakamura K, Fukumoto M, Ohmori K, Ohno $Y$ and Nakao K. A newly established megakaryoblastic/ erythroid cell line that differentiates to red cells in the presence of erythropoietin and produces platelet-like particles. Stem Cells 1995; 13: 54-64.

7. Byatnal A, Byatnal AA, Parvathi Devi MK and Badriramkrishna B. beta-Thalassemia hijacking ineffective erythropoietin and iron overload: Two case reports and a review of literature. J Nat Sci Biol Med 2014; 5: 456-459.

8. Celik M, Gokmen N, Erbayraktar S, Akhisaroglu M, Konakc S, Ulukus C, Genc S, Genc K, Sagiroglu E, Cerami $A$ et al. Erythropoietin prevents motor neuron apoptosis and neurologic disability in experimental spinal cord ischemic injury. Proc Natl Acad Sci U S A 2002; 99: 2258-2263.

9. Van Wyck DB, Roppolo M, Martinez CO, Mazey RM, McMurray $S$ and United States Iron Sucrose Clinical Trials G. A randomized, controlled trial comparing IV iron sucrose to oral iron in anemic patients with nondialysis-dependent CKD. Kidney Int 2005; 68: 2846 2856.

10. Ostberg KL, DeRocco AJ, Mistry SD, Dickinson MK and Cornelissen $C N$. Conserved regions of gonococcal $T b p B$ are critical for surface exposure and transferrin iron utilization. Infect Immun 2013; 81: 3442-3450.

11. Xue CE, Shen $Q H$, Wang $Y$, Zhang JY and Lin FR. Clinical Significance of the Serum EPO Level in Patients with Iron Deficiency Anemia. Zhongguo Shi Yan Xue Ye Xue Za Zhi 2015; 23: 1410-1414.

12. Debska-Slizien A, Owczarzak A, Kunicka D, LysiakSzydlowska $W$ and Rutkowski B. Plasma carnitine profile during chronic renal anemia treatment with recombinant human erythropoietin. Int $J$ Artif Organs 2003; 26: 33-38.

13. Di lorio BR, Guastaferro P, Cillo N, Cucciniello $E$ and Bellizzi V. Long-term L-carnitine administration reduces erythropoietin resistance in chronic hemodialysis patients with thalassemia minor. Drug Target Insights 2007; 2: 1-7.

14. Aoun B, Berard E, Vitkevic R, Dehee A, Bensman A and Ulinski T. L-carnitine supplementation and EPO requirement in children on chronic hemodialysis. Pediatr Nephrol 2010; 25: 557-560.

15. Boran M, Dalva I, Gonenc F and Cetin S. Response to recombinant human erythropoietin $(r-H u E P O)$ and $L$ carnitine combination in patients with anemia of endstage renal disease. Nephron 1996; 73: 314-315.
16. Emami Naini A, Moradi M, Mortazavi M, Amini Harandi A, Hadizadeh M, Shirani F, Basir Ghafoori $H$ and Emami Naini P. Effects of Oral L-Carnitine Supplementation on Lipid Profile, Anemia, and Quality of Life in Chronic Renal Disease Patients under Hemodialysis: A Randomized, Double-Blinded, Placebo-Controlled Trial. J Nutr Metab 2012; 2012: 510483.

17. Larramendi CH, Marco FM, Garcia-Abujeta JL, Mateo M, de la Vega $A$ and Sempere JM. Acute allergic reaction to an iron compound in a milk-allergic patient. Pediatr Allergy Immunol 2006; 17: 230-233.

18. Ksiazek A. Effect of recombinant human erythropoietin ( $r$ Hu EPO) therapy on blood pressure in dialysis patients. Ann Univ Mariae Curie Sklodowska Med 1994; 48 Suppl 3: 23-28.

19. Zachara BA, Gromadzinska J, Wasowicz W and Zbrog Z. Red blood cell and plasma glutathione peroxidase activities and selenium concentration in patients with chronic kidney disease: a review. Acta Biochim Pol 2006; 53: 663-677.

20. Ghorbani M, Vatannejad A, Khodadadi I, Amiri I and Tavilani $H$. Protective Effects of Glutathione Supplementation against Oxidative Stress during Cryopreservation of Human Spermatozoa. Cryo Letters 2016; 37: 34-40.

21. Zhu XH, Liu B and Cheng ZY. Diagnostic value of serumascites albumin gradient. Hunan Yi Ke Da Xue Xue Bao 2003; 28: 278-280.

22. Wang C, Wang W, Ma S, Lu J, Shi $H$ and Ding $F$. Reduced Glutathione for Prevention of Renal Outcomes in Patients Undergoing Selective Coronary Angiography or Intervention. J Interv Cardiol 2015; 28: 249-256.

23. Ando D, Yamakita $M$, Yamagata $Z$ and Koyama $K$. Effects of glutathione depletion on hypoxia-induced erythropoietin production in rats. J Physiol Anthropol 2009; 28: 211-215.

24. Chaturvedi $R$, Chattopadhyay $P$, Banerjee $S$, Bhattacharjee CR, Raul $P$, Borah $K$, Singh $L$ and Veer $V$. Iron-rich drinking water and ascorbic acid supplementation improved hemolytic anemia in experimental Wistar rats. Int J Food Sci Nutr 2014; 65: 856-861.

25. Eiselt J, Racek J, Trefil $L$ and Opatrny $K$, Jr. Effects of a vitamin E-modified dialysis membrane and vitamin $C$ infusion on oxidative stress in hemodialysis patients. Artif Organs 2001; 25: 430-436.

26. Egbi G, Ayi I, Saalia FK, Zotor F, Adom T, Harrison E, Ahorlu CK and Steiner-Asiedu M. Impact of CowpeaBased Food Containing Fish Meal Served With Vitamin C-Rich Drink on Iron Stores and Hemoglobin Concentrations in Ghanaian Schoolchildren in a Malaria Endemic Area. Food Nutr Bull 2015; 36: 264-275.

27. Vijayprasad $S, B b G$ and $B b N$. Effect of vitamin $C$ on male fertility in rats subjected to forced swimming stress. Journal of clinical and diagnostic research JCDR 2014; 8: HCO5-08.

28. Peters $C D$, Kjaergaard $K D$, Jensen $J D$, Christensen $K L$, Strandhave C, Tietze IN, Novosel MK, Bibby BM and 
Jespersen B. Short and Long-Term Effects of the Angiotensin II Receptor Blocker Irbesartan on Intradialytic Central Hemodynamics: A Randomized Double-Blind Placebo-Controlled One-Year Intervention Trial (the SAFIR Study). PLoS One 2015; 10: e0126882.

29. Ordaz-Medina SM, Gonzalez-Plascencia J, Martin del Campo F, Rojas-Campos E, Montanez-Fernandez JL, Espinoza-Gomez $F$ and Cueto-Manzano AM. Is systemic inflammation of hemodialysis patients improved with the use of enalapril? Results of a randomized, double-blinded, placebo-controlled clinical trial. ASAIO J 2010; 56: 37-41.

30. Tasic NM, Tasic $D$, Otasevic $P$, Veselinovic $M$, Jakovljevic $V$, Djuric $D$ and Radak $D$. Copper and zinc concentrations in atherosclerotic plaque and serum in relation to lipid metabolism in patients with carotid atherosclerosis. Vojnosanit Pregl 2015; 72: 801-806.

31. Tvrda E, Peer R, Sikka SC and Agarwal A. Iron and copper in male reproduction: a double-edged sword. J Assist Reprod Genet 2015; 32: 3-16.

32. Yoshihara D, Fujiwara $N$, Kato $S$, Sakiyama $H$, Eguchi $H$ and Suzuki $K$. Alterations in renal iron metabolism caused by a copper/zinc-superoxide dismutase deficiency. Free Radic Res 2012; 46: 750-757.

33. Macdougall IC and Cooper AC. Erythropoietin resistance: the role of inflammation and pro-inflammatory cytokines. Nephrol Dial Transplant 2002; 17 Suppl 11: 39-43.

34. Costa E, Lima M, Alves JM, Rocha S, Rocha-Pereira $P$, Castro E, Miranda $V$, do SF, Loureiro A, Quintanilha A et al. Inflammation, $T$-cell phenotype, and inflammatory cytokines in chronic kidney disease patients under hemodialysis and its relationship to resistance to recombinant human erythropoietin therapy. J Clin Immunol 2008; 28: 268-275.

35. Sitter T, Bergner $A$ and Schiffl H. Dialysate related cytokine induction and response to recombinant human erythropoietin in haemodialysis patients. Nephrol Dial Transplant 2000; 15: 1207-1211.
36. Wu G, Wadgymar A, Wong $G$, Ting $R$, Nathoo $B$, Mendelssohn D, Pandeya S, Sapir D and Tam P. A cross-sectional immunosurveillance study of anti-EPO antibody levels in CRF patients receiving epoetin alfa in 5 Ontario Renal Centers. Am J Kidney Dis 2004; 44: 264-269.

37. Vota $D M$, Crisp RL, Nesse $A B$ and Vittori $D C$. Oxidative stress due to aluminum exposure induces eryptosis which is prevented by erythropoietin. J Cell Biochem 2012; 113: 1581-1589.

38. Reuter SE, Faull RJ, Ranieri $E$ and Evans AM. Endogenous plasma carnitine pool composition and response to erythropoietin treatment in chronic haemodialysis patients. Nephrol Dial Transplant 2009; 24: 990-996.

39. Heinze G, Collins S, Benedict MA, Nguyen LL, Kramar R, Winkelmayer WC, Haas M, Kainz $A$ and Oberbauer $R$. The association between angiotensin converting enzyme inhibitor or angiotensin receptor blocker use during postischemic acute transplant failure and renal allograft survival. Transplantation 2006; 82: 1441-1448.

40. Macdougall IC. The role of ACE inhibitors and angiotensin II receptor blockers in the response to epoetin. Nephrol Dial Transplant 1999; 14: 1836-1841.

41. Saudan P, Halabi G, Perneger T, Wasserfallen JB, Wauters JP, Martin $P Y$ and Western Switzerland Dialysis G. ACE inhibitors or angiotensin II receptor blockers in dialysed patients and erythropoietin resistance. J Nephrol 2006; 19: 91-96.

42. Jeong KH, Lee TW, Ihm CG, Lee SH and Moon JY. Polymorphisms in two genes, IL-1B and ACE, are associated with erythropoietin resistance in Korean patients on maintenance hemodialysis. Exp Mol Med 2008; 40: 161-166.

43. Rosati A, Tetta C, Merello JI, Palomares I, Perez-Garcia $R$, Maduell F, Canaud $B$ and Aljama Garcia $P$. Cumulative iron dose and resistance to erythropoietin. $J$ Nephrol 2015; 28: 603-613. 